\title{
Rete Testis Neoplasm
}

National Cancer Institute

\section{Source}

National Cancer Institute. Rete Testis Neoplasm. NCI Thesaurus. Code C39955.

A benign or malignant neoplasm that affects the rete testis. Representative examples include adenoma and adenocarcinoma. 